\title{
Evaluation of ultraviolet light toxicity on cultured retinal pigment epithelial and retinal ganglion cells
}

This article was published in the following Dove Press journal:

Clinical Ophthalmology

6 January 2010

Number of times this article has been viewed

\author{
Sankarathi Balaiya \\ Ravi K Murthy \\ Vikram S Brar \\ Kakarla $\vee$ Chalam \\ Department of Ophthalmology, \\ University of Florida College \\ of Medicine, Jacksonville, \\ FL, USA
}

Correspondence: Kakarla V Chalam University of Florida, Department of Ophthalmology, 580 West 8th Street, Tower II, 3rd Floor, Jacksonville, FL 32209, USA

$\mathrm{Tel}+$ I 904244939 |

Fax + I 9042449391

Email kchalam@jax.ufl.edu
Purpose: Our study is aimed at evaluating the role of UVB light in inducing cytotoxicity in an in vitro model.

Methods: RGC-5 and ARPE-19 cells were exposed to different time periods of UVB light: 0, 15, 30 , and $45 \mathrm{~min}$. They were subsequently examined for changes in cell morphology, cell viability (neutral red uptake assay), generation of reactive oxygen species (ROS), expression of bax, bcl-2 and cytochome $\mathrm{C}$ by reverse transcriptase polymerase chain reaction and western blot, respectively.

Results: Dose-dependent reduction in cell viability to UVB light was demonstrated with parallel increase in ROS. Increased duration of exposure ( $>15$ minutes), was associated with increased expression of bax and cytochrome $\mathrm{C}$, and absence of bcl-2 expression.

Conclusion: UVB light exposure results in cell cytotoxicity. The concomitant generation of ROS and expression of apoptotic markers suggests the role of oxidative stress in UVB-mediated apoptosis in an in vitro model of retinal ganglion and pigment epithelial cells.

Keywords: ultraviolet light, retinal pigment epithelium, retinal ganglion cell, reactive oxygen species, cytochrome $\mathrm{C}$

\section{Introduction}

Age-related macular degeneration (AMD) is the leading cause of blindness in the Western world. ${ }^{1}$ Age, race, and smoking are known risk factors associated with the development of AMD. ${ }^{2,3}$ High levels of endogenous pigments, which act as photosensitizers, and increased metabolic activity in the posterior pole of the eye predisposes macula to light-induced oxidative stress and consecutive degeneration. ${ }^{4}$ Though the human retina is protected by the cornea and lens from short wavelength radiation $(<400 \mathrm{~nm})$, retinal damage has been reported with varying intensity, wavelength, and duration of exposure. ${ }^{5}$ Ultraviolet (UV) light induces apoptosis in the human retinal pigment epithelial (RPE) cells. ${ }^{6}$ The underlying mechanism in the induction of apoptosis is the production of reactive oxygen species (ROS) ${ }^{7,8}$ However, the effect of UV light on other retinal cell types such as ganglion cells, which are not as metabolically active as RPE, is not known. In this study we evaluated the toxic effect of UVB light on retinal ganglion and pigment epithelial cells to highlight any difference seen in these two cell lines. The toxic effect was evaluated with measurement of ROS and induction of pro-apoptotic markers.

\section{Methods}

\section{Cell culture}

Rat retinal ganglion cells (RGC-5) (courtesy of Dr. Neeraj Agarwal, UNT Health Science Center, TX) and human retinal pigment epithelial cells (ARPE-19; ATCC, Manassas, VA) 
were cultured in Dulbecco's modified Eagle's medium (DMEM; Invitrogen, Carlsbad, CA) and DMEM/F12 respectively, media supplemented with 10\% fetal bovine serum (FBS) and $100 \mathrm{U} / \mathrm{mL}$ penicillin $/ 100 \mu \mathrm{g} / \mathrm{mL}$ streptomycin. All cells were maintained in log rhythmic growth in T-75 flask ware incubated at $37{ }^{\circ} \mathrm{C}$ in a $95 \%$ air and $5 \% \mathrm{CO}_{2}$ environment.

\section{In vitro UVB irradiation}

The RGC-5 and ARPE-19 cells were seeded in 24-well plates (Greiner Bio-One, Grapevine, TX) at a density of $3 \times 10^{5}$ cells/well. Conditioned media from confluent cells was removed, and incubated with fresh media at $37^{\circ} \mathrm{C}$ for $30 \mathrm{~min}$ before UV irradiation. The UV irradiation lamp (Hoefer Scientific, San Francisco, CA) has a mid-range wavelength of $302 \mathrm{~nm}$ with a filter size of $21 \mathrm{~cm} \times 25 \mathrm{~cm}$ and exposure intensity of $7,000 \mu \mathrm{W} / \mathrm{cm}^{2}$. After incubation, culture medium was aspirated and replaced with Hank's balanced salt solution (HBSS; Gibco, Invitrogen) for UV exposure. During the irradiation, the cultures were exposed to UVB irradiation at $302 \mathrm{~nm}$ for 15, 30, and $45 \mathrm{~min}$; unexposed cells served as controls. The cells were subsequently washed twice with HBSS and conditioned media was replaced. The experiment was concluded after $24 \mathrm{~h}$ incubation at which point cell morphology and viability were evaluated.

\section{Cell morphology}

After $24 \mathrm{~h}$ of recovery, morphological changes of post-UV radiated retinal ganglion and pigment epithelial cells were observed using bright field phase contrast microscopy (Olympus $1 \times 51$; Long Island, NY). In each condition, 100 cells were chosen randomly and morphological changes were noted and compared with unexposed cells.

\section{Neutral red uptake assay}

Following UVB exposure, cell viability was assayed using neutral red assay (Sigma-Aldrich, St. Louis, MO), where viable cells store the dye in intracellular lysosomes, via active transport. ${ }^{9}$ In brief, cells were incubated with the dye (final concentration $0.033 \%$ ) for $2 \mathrm{~h}$ at room temperature and were subsequently washed with HBSS. Cells were allowed to air dry for $20 \mathrm{~min}$ and retained dye was eluted using ice-cold solubilization buffer ( $1 \%$ acetic acid $/ 50 \%$ ethanol; $300 \mu \mathrm{l})$. Twenty minutes later, $100 \mu \mathrm{l}$ aliquots were transferred to 96-well plates (Greiner Bio-One) for optical density readings at $490 \mathrm{~nm}$.

\section{Measurement of ROS}

$1 \times 10^{5}$ of RGC-5 and ARPE-19 were plated in 24-well plates. Cells were allowed to attach and subsequently exposed to
UVB for 15 and $30 \mathrm{~min}$; unexposed cells served as controls. ROS levels were evaluated as described previously ${ }^{10}$ using dihydrorhodamine 123 (DHR 123; AnaSpec, Fremont, CA). In brief, conditioned media of each well was replaced with desired volume of $10 \mu \mathrm{M}$ DHR 123 and the fluorescence was measured by spectrophotometer between the wavelength range of $485-528 \mathrm{~nm}$.

\section{RT-PCR}

Reverse transcriptase polymerase chain reaction (RT-PCR) was conducted to evaluate presence/absence of the apoptotic marker bax and the antiapoptotic marker bcl-2. cDNA was isolated from RGC-5 and ARPE-19 cells according to manufacturer's instructions (Ambion, St. Austin, TX). Briefly, $100 \mu \mathrm{l}$ of ice-cold cell lysis buffer was added to the isolated cells and incubated at $75^{\circ} \mathrm{C}$ for $10 \mathrm{~min}$. The genomic DNA was degraded with $2 \mu \mathrm{l}$ of DNase I at $37^{\circ} \mathrm{C}$ for $15 \mathrm{~min}$, and deactivated by heating to $75^{\circ} \mathrm{C}$ for $5 \mathrm{~min}$. Reverse transcription was performed using $2 \mu \mathrm{M}$ Oligo(dT $)_{18}$ primers. The isolated cDNA was normalized with respect to the expression of glyceraldehyde-3-phosphate dehydrogenase (GAPDH), a house keeping gene. From the isolated cDNA, apoptotic and antiapoptotic marker expression were observed using 5 pmole/ $\mu$ l of primer (bax F: 5'-GTTTCATCCAGGATC GAGCAG-3', and R: 5'-TGCCTGCTTCCZGATG GTGA-3'; bcl-2 F: 5'-CCTGTGGATGACTGAGTACC-3', and R: 5'-GAGACAGCCAGGAGAAATCA-3') under the conditions of $95{ }^{\circ} \mathrm{C} / 30 \mathrm{sec}, 53{ }^{\circ} \mathrm{C} / 40 \mathrm{sec}, 72{ }^{\circ} \mathrm{C} / 40 \mathrm{sec}$ for 30 cycles. The PCR products were separated on agarose gel electrophoresis in the presence of ethidium bromide and documented using gel documentation system (ChemiDoc; Bio Rad Laboratories, Hercules, CA). The products of each reaction were confirmed against $1 \mathrm{~kb}$ DNA markers (Invitrogen).

\section{Western blot analysis}

The presence of the apoptotic marker cytochrome $\mathrm{C}$ was evaluated using western blot. RGC-5 and ARPE-19 cells were counted and processed for protein isolation according to the manufacturer's instructions (Ambion). In brief, protein was isolated by adding $300 \mu \mathrm{l}$ of ice-cold cell disruption buffer. After obtaining a homogenous lysate, the samples were centrifuged and mixed in equal volume with $1 \times$ SDS Tris-glycine buffer. The samples (approximately $2-5 \times 10^{4}$ cells) were resolved in a $10 \%$ SDS-polyacrylamide gel electrophoresis at 200 volts-hour (Vh). The protein profile was transblotted onto nitrocellulose membrane (Sigma Aldrich) at $30 \mathrm{~V}$ kept overnight. Antibody detection was done with the use of WesternBreeze Chromogenic Immunodetection Kit (Invitrogen). After blocking with 
provided blocking solution, the membrane was incubated with primary antibody against human cytochrome C (Sigma Aldrich). The signal was revealed by incubation with secondary antibody solution and detected with chromogenic substrate (Sigma Aldrich).

\section{Results}

\section{Structural morphology}

A filamentous monolayer of RGC-5 cells revealed characteristic features after varying time points of UV exposure. They became cuboidal in shape and demonstrated blebs in $50 \%$ of the cells after $15 \mathrm{~min}$ of UV exposure. After 30 and $45 \mathrm{~min}$ of UV exposure, $60 \%$ and $70 \%$ of the cells were crenated, respectively. Membrane rupture was observed in $24 \%$ of the cells at $30 \mathrm{~min}$ exposure, which increased to $44 \%$ at $45 \mathrm{~min}$ (Figure 1).
In ARPE-19 cells, 22\% developed blebs after 15 min of UV exposure. Other apoptotic features like large vacuoles were present in $12 \%$ of the cells after 30 min of UV exposure. With 45 min of exposure, $90 \%$ of the cells showed increase in size with irregular cell borders. Membrane rupture was observed in 33\% after $30 \mathrm{~min}$ exposure which increased to $47 \%$ after 45 min of UV exposure (Figure 2).

\section{Neutral red uptake assay}

We observed that there was a significant reduction in lysosomal membrane integrity in RGC-5 cells at 15 to $45 \mathrm{~min}$ of exposure to UVB $(P<0.00005)$. In comparison with control, only $45 \%$ of cells were viable after $15 \mathrm{~min}$ of exposure to UVB, which further decreased to $13 \%$ after $45 \mathrm{~min}$ of exposure. Similarly, in ARPE-19 cells, in comparison to control, $56 \%$ of cells were viable after $15 \mathrm{~min}$ of UV
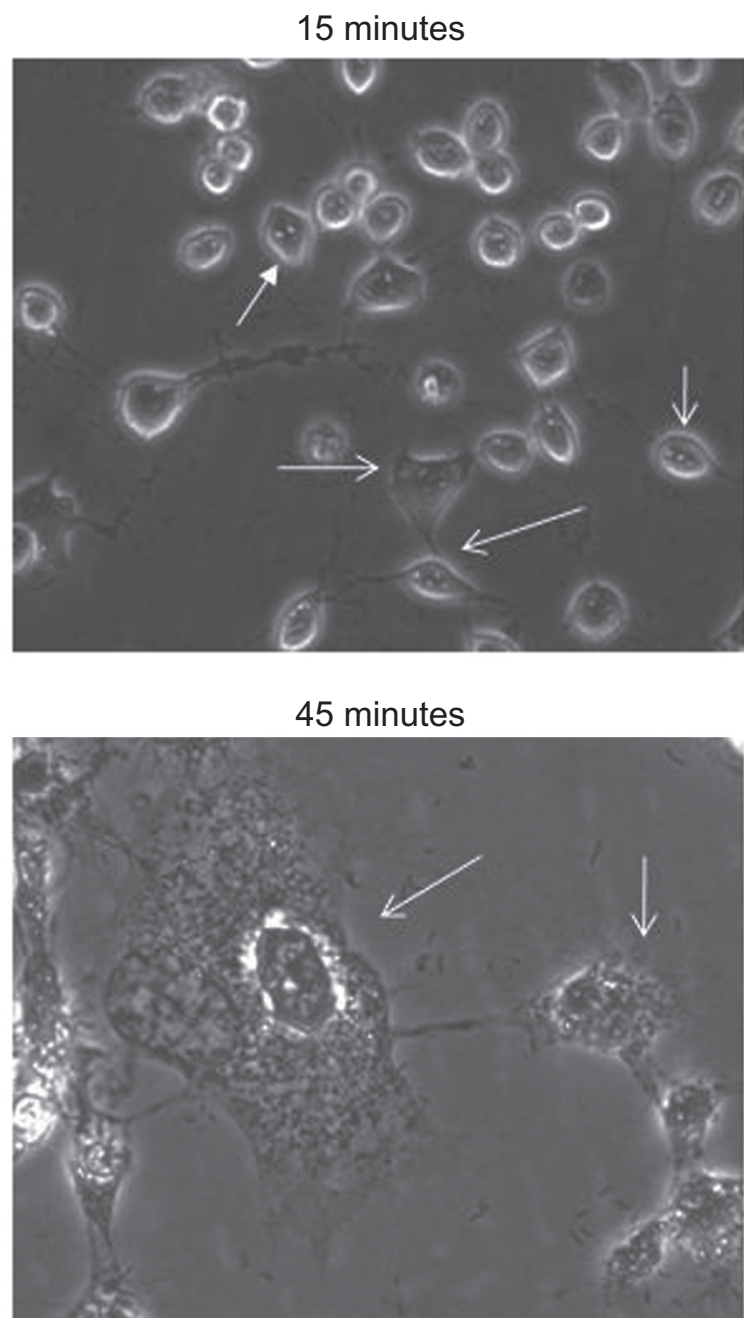

Figure I Phase contrast micrographs show the presence of morphological changes such as bleb formation and membrane rupture observed in RGC-5 cells after various time points of UVB exposure. 
Control

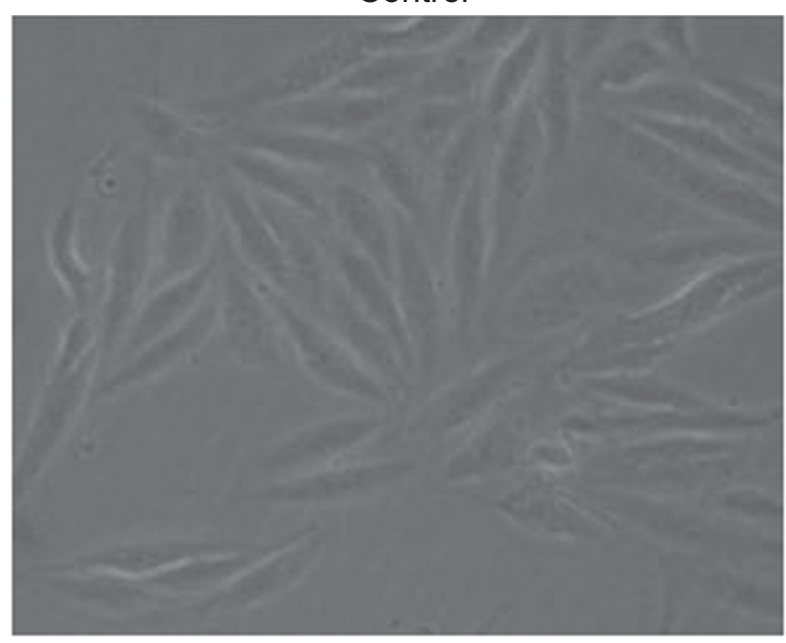

30 minutes

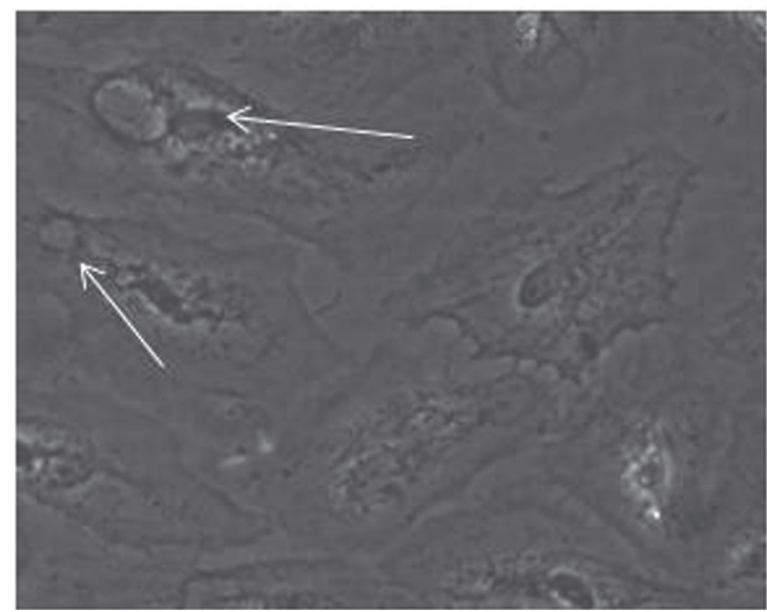

15 minutes

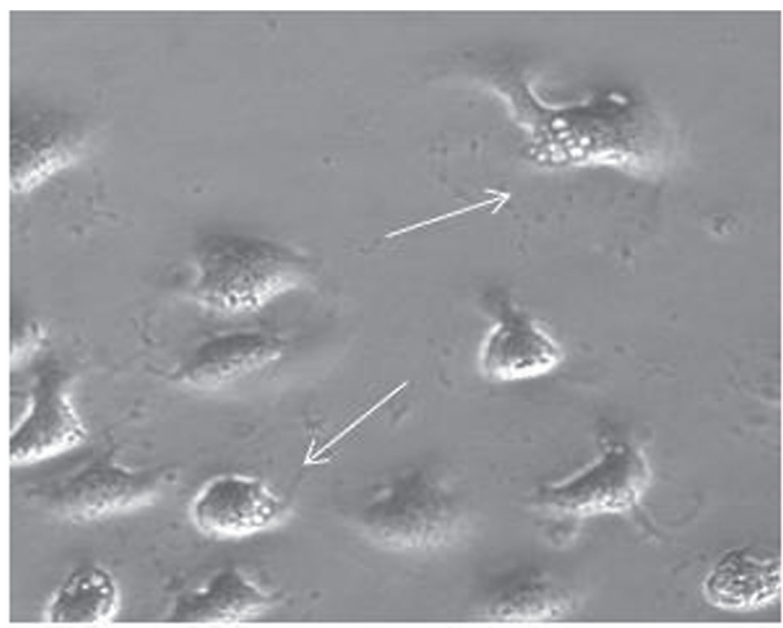

45 minutes

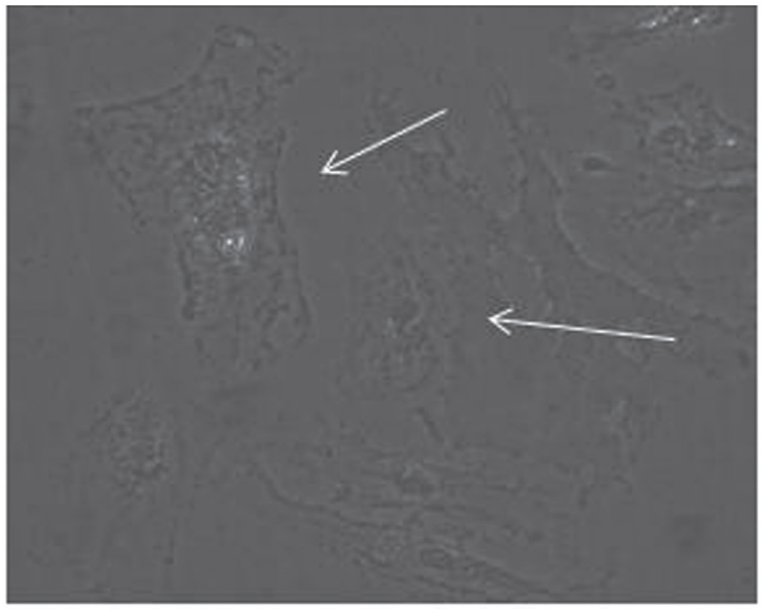

Figure 2 Phase contrast micrographs shows the presence of morphological changes such as bleb formation, vacuolation, and membrane rupture observed in ARPE-19 cells after various time points of UVB exposure.

exposure which decreased to $13 \%$ after 45 min exposure $(P<0.0005)$ (Figure 3).

\section{Intracellular ROS}

RGC-5 exposed to UV showed $83 \%$ increase of ROS level after $15 \mathrm{~min}$ and $114 \%$ increase after $30 \mathrm{~min}$ of UV exposure compared to control $(P<0.00005$; Figure 3$)$. ARPE-19 cells showed $100 \%$ increase of ROS level after $15 \mathrm{~min}$ and $150 \%$ increase after $30 \mathrm{~min}$ of UV exposure compared to control $(P<0.00005$; Figure 4).

\section{RT-PCR}

Apoptotic and antiapoptotic markers, Bax (486 bp) and Bcl-2 (128 bp) were confirmed against $1 \mathrm{~kb}$ ladder in 2\% and 3\% agarose gel electrophoresis, respectively. No bands were detected using apoptotic bax primer in experimental cells up to 15 min after UV treatment. Cells harvested after 30 to $45 \mathrm{~min}$ exposure showed a significant increase of bax and a decrease or no band in $b c l-2$ relative to control. cDNA levels were normalized using house-keeping gene GAPDH (Figure 5).

\section{Western blot assay}

No conjugate band identification was observed prior to the 15 min exposure to UVB. However, when the UV-B irradiation was carried out at $15 \mathrm{~min}$, cytochrome-C positive bands was detected through the $45 \mathrm{~min}$ period.

\section{Discussion}

Oxidative stress and reactive oxygen species have been implicated in the pathogenesis of AMD. ${ }^{8,11}$ Chronic oxidative damage on the RPE cells as result of exposure to UV light 
RGC-5

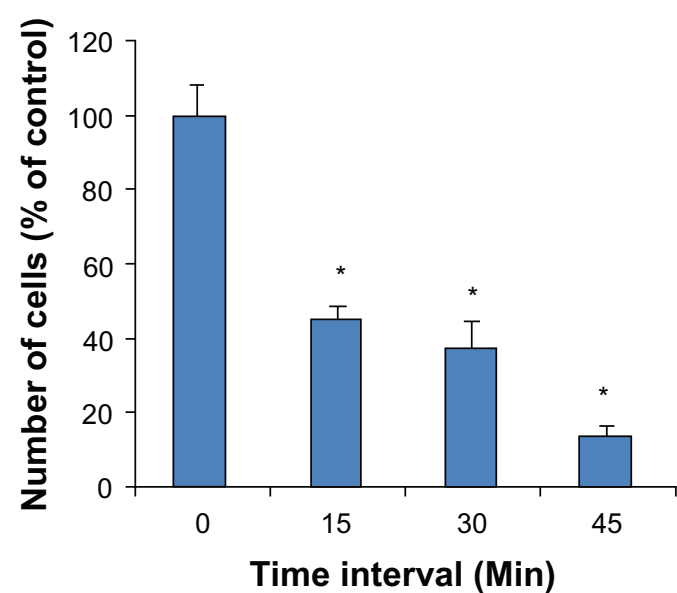

ARPE-19

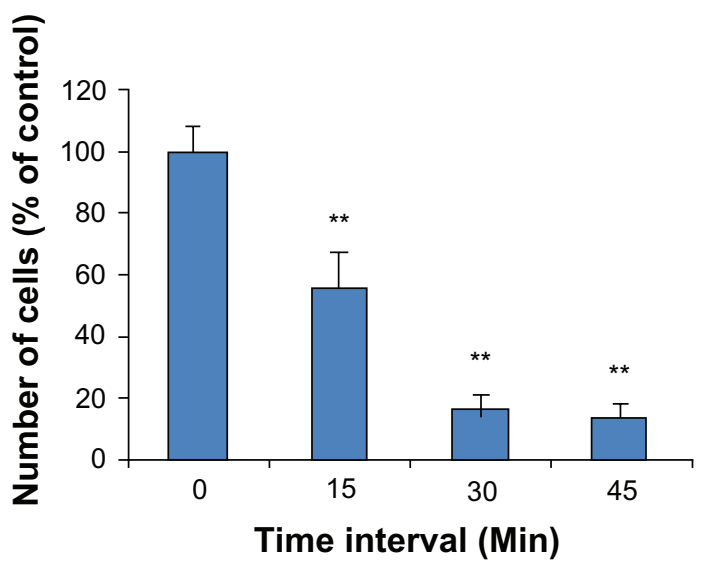

Figure 3 Viability of retinal ganglion and pigment epithelial cells after 15, 30, and 45 min exposure to UVB light. Notes: $* P<0.00005$, $* * P<0.0005$.

results in its atrophy. ${ }^{8}$ Hypothetically, retinal ganglion cells provide an additional UV filter in addition to cornea and lens, before outer segments of photoreceptors and cells of the pigment epithelium are reached by the hazardous radiation. ${ }^{12}$ In our study, we demonstrate that UVB light exposure is cytotoxic to both the retinal ganglion cells and retinal pigment epithelial cells by a dose-dependent increase in ROS, indicating that the reduction in cell viability following UVB exposure involves oxidative stress.

The specific sensitivity of RPE to damage by the UV light is a result of its high metabolic rate and presence of intracellular photosensitizers. ${ }^{4}$ On the contrary, RGC are less active metabolically and are devoid of any kind of photosensitizing pigment. So hypothetically, RGC must be less sensitive to UV light damage as compared to the RPE. However, in our

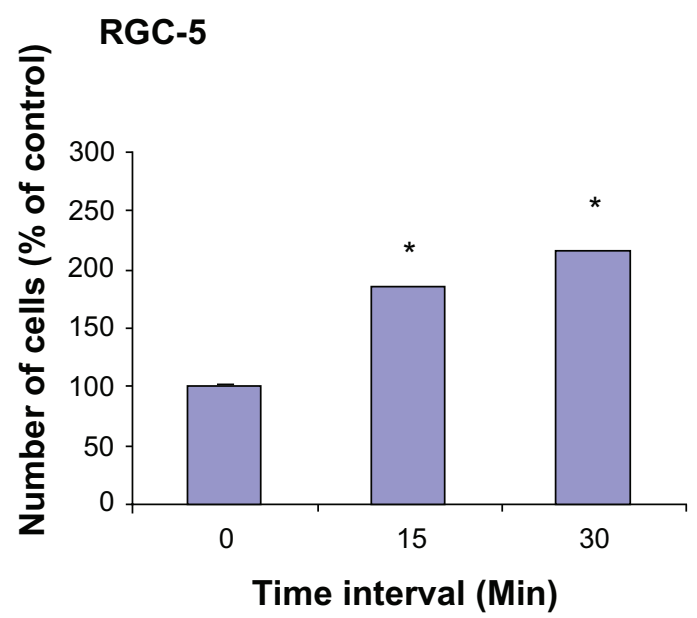

study, we found UVB light to be equally cytotoxic on both RGC and RPE cells. The expression of bax and the absence of bcl-2 following 30 and $45 \mathrm{~min}$ exposure support the role of UV-B in the induction of apoptosis. Similar observations have been recorded in transformed murine fibroblasts after exposure to UV light. ${ }^{13}$

Light exposure promotes lipid peroxidation of cellular membranes by triggering photo-oxidation reactions resulting in the formation of ROS. ${ }^{14}$ In our study, increased ROS production was noted in both the RGC and RPE cell lines after UV light suggesting an intermediary role for oxidative stress in the induction of apotosis. Similar results have been documented by Liang and colleagues who have shown ROS to be involved in the induction of apoptosis in RPE cells exposed to UV light. $^{8}$

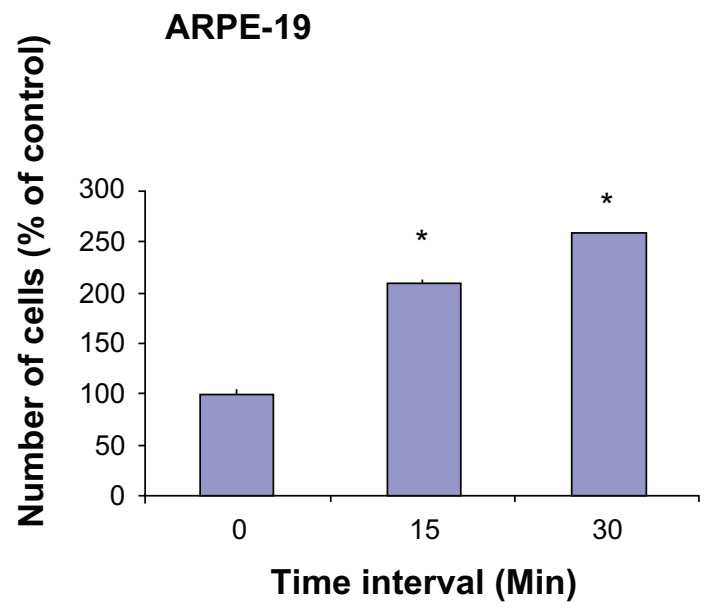

Figure 4 ROS levels assessed by DHRI 23 after exposure to different time points of UVB exposure.

Note: $* P<0.00005$.

Abbreviation: ROS, reactive oxygen species. 

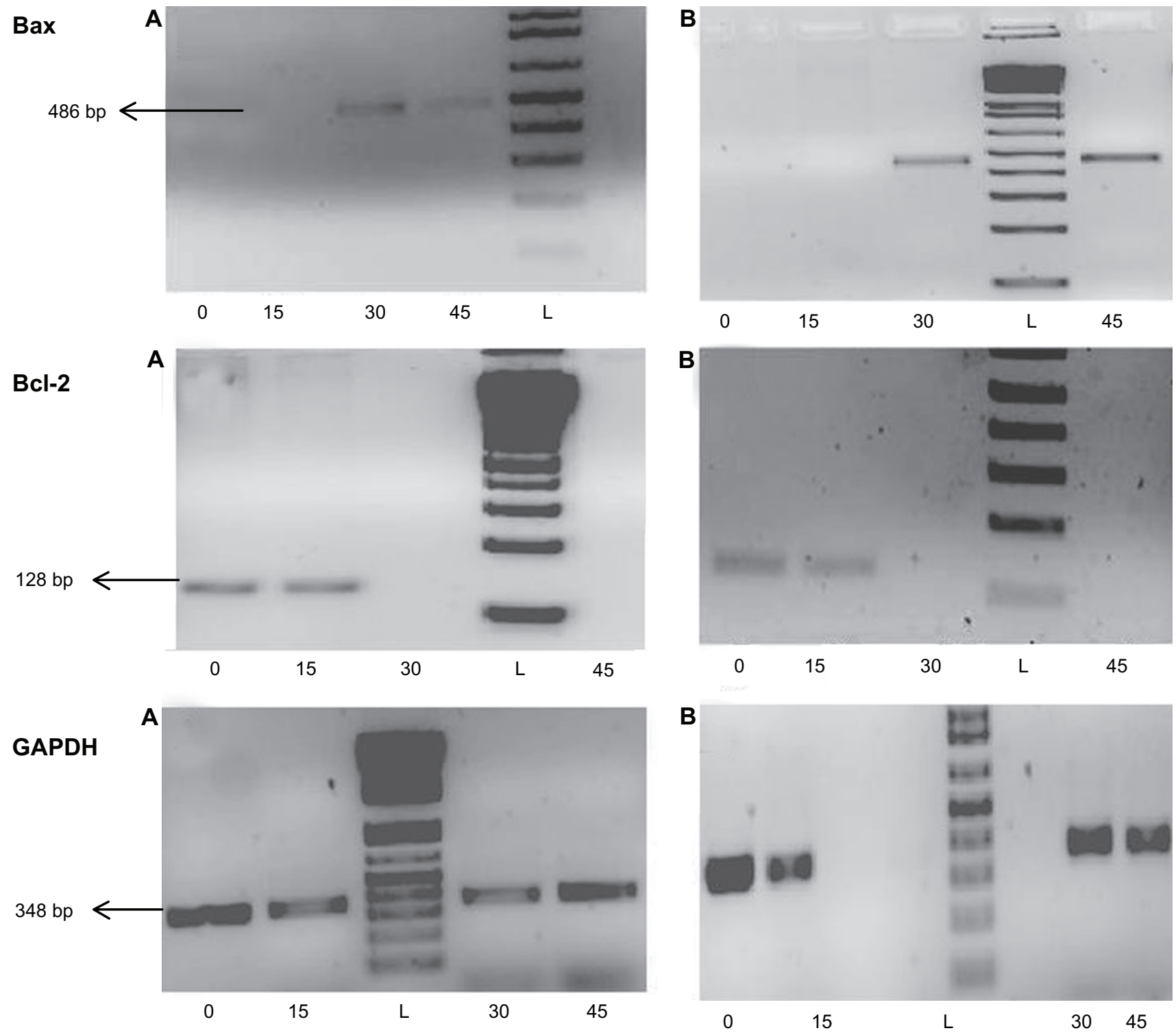

Figure 5 Electrophoregram illustrating the presence of pro (Bax, 486 bp) and antiapoptotic marker (Bcl-2, I28 bp) expression in ARPE-19 and RGC-5 cells after 0, I5, 30, 45 min exposure to UV radiation.

Notes: A, RGC-5; B, ARPE-19; L, 100 bp ladder; Control, GAPDH (348 bp).

Mitochondria represent a primary site of phototoxicity induced by UV radiation, as described in studies of mitochondrial enzyme activity of murine fibroblast cells and human kertinocytes. ${ }^{15,16} \mathrm{~A}$ mitochondrial dependent pathway has also been implicated in the mechanism of induction of apoptosis in RPE cells. ${ }^{6}$ In addition, increased ROS production after UV radiation exposure correlates well with decreased mitochondrial membrane potential, a marker for mitochondrial function. ${ }^{17}$ In our study we demonstrated the release of cytochome $\mathrm{C}$ in UVB exposed cells suggesting the involvement of mitochondria.

In conclusion, the results of this study confirm altered cellular viability and mitochondrial function of both retinal ganglion cells and retinal pigment epithelial cells after exposure to UVB radiation in a dose-dependent manner with the cytotoxicity mediated through generation of ROS.

\section{Disclosures}

The authors report no conflicts of interest in this work.

\section{References}

1. National Advisory Eye Council (US). Vision Research: A National Plan 1994-1998. NIH publication no. 93-3186. Bethesda, MD: US Department of Health and Human Services; 1993.

2. Tomany SC, Wang JJ, van Leeuwen R, et al. Risk factors for Incident age-related macular degeneration. Ophthalmology. 2004;111(7): $1280-1287$. 
3. Clemons TE, Milton RC, Klein R, et al; Age-Related Eye Disease Study Research Group. Risk factors for the incidence of advanced age-related macular degeneration in the Age-Related Eye Disease Study (AREDS) AREDS report number 19. Ophthalmology. 2005;112(4):533-539.

4. Loane E, Kelliher C, Beatly S, Nolan JM. The rationale and evidence for a protective role of macular pigment in age-related maculopathy. Br J Ophthalmol. 2008;92:1163-1168.

5. Wood JPM, Lascaratos G, Bron AJ, Osborne NN. The influence of visible light exposure on cultured RGC-5 cells. Mol Vis. 2008;14:334-344.

6. Roduit R, Schorderet DF. MAP kinase pathways in UV-induced apoptosis of retinal pigment epithelium ARPE19 cells. Apoptosis. 2008;13:343-353.

7. Simon HU, Haj-Yehia A, Levi-Schaffer F. Role of reactive oxygen species (ROS) in apoptosis induction. Apoptosis. 2000;5(5):415-418

8. Liang FQ, Godley BF. Oxidative stress-induced mitochondrial DNA damage in human retinal pigment epithelial cells: a possible mechanism for RPE aging and age-related macular degeneration. Exp Eye Res. 2003;76(4):397-403.

9. Borenfreund E, Puerner JA. Toxicity determined in vitro by morphological alterations and neutral red absorption. Toxicol Lett. 1985;24(2-3): 119-124.

10. Katiyar SK, Afaq F, Azizuddin K, Mukhtar H. Inhibition of UVB induced oxidative stress-mediated phosphorylation of mitogen-activated protein kinase signaling pathways in cultured human epidermal keratinocytes by green tea polyphenol (-)-epigallocatechin-3-gallate. Toxicol Appl Pharmacol. 2001;176:110-117.
11. Beatty S, Koh H, Phil M, Henson D, Boulton M. The role of oxidative stress in the pathogenesis of age-related macular degeneration. Surv Ophthalmol. 2000;45(2):115-134.

12. Sliney DH. How light reaches the eye and its components. Int JToxicol. 2002;21(6):501-509.

13. Naik E, Michalak EW, Villunger A, Adams JM, Strasser A. Ultraviolet radiation triggers apoptosis of fibroblasts and skin keratinocytes mainly via the BH3-only protein. J Cell Biol. 2007;176(4):415-424.

14. De la Paz MA, Anderson RE. Lipid peroxidation in rod outer segments. Role of hydroxyl radical and lipid hydroperoxides. Invest Ophthalmol Vis Sci. 1992;33:2091-2096.

15. Masaki H, Sakurai H. Increased generation of hydrogen peroxide possibly from mitochondrial respiratory chain after UVB irradiation of murine fibroblasts. Dermatol Sci. 1997;14(3):207-216.

16. Paz ML, González Maglio DH, Weill FS, Bustamante J, Leoni J. Mitochondrial dysfunction and cellular stress progression after ultraviolet B irradiation in human keratinocytes. Photodermatol Photoimmunol Photomed. 2008;24(3):115-122.

17. Wang CC, Fang KM, Yang CS, Tzeng SF. Reactive oxygen speciesinduced cell death of rat primary astrocytes through mitochondriamediated mechanism. Cell Biochem. 2009;107(5):933-943.
Clinical Ophthalmology

\section{Publish your work in this journal}

Clinical Ophthalmology is an international, peer-reviewed journal covering all subspecialties within ophthalmology. Key topics include: Optometry; Visual science; Pharmacology and drug therapy in eye diseases; Basic Sciences; Primary and Secondary eye care; Patient Safety and Quality of Care Improvements. This journal is indexed on

Submit your manuscript here: http://www.dovepress.com/clinical-ophthalmology-journal

\section{Dovepress}

PubMed Central and CAS, and is the official journal of The Society of Clinical Ophthalmology (SCO). The manuscript management system is completely online and includes a very quick and fair peer-review system, which is all easy to use. Visit http://www.dovepress.com/ testimonials.php to read real quotes from published authors. 